University of Nebraska - Lincoln

DigitalCommons@University of Nebraska - Lincoln

\title{
Past and projected future changes in snowpack and soil frost at the Hubbard Brook Experimental Forest, New Hampshire, USA
}

\author{
John L. Campbell \\ USDA Forest Service, jlcampbell@fs.fed.us \\ Scott V. Ollinger \\ University of New Hampshire \\ Gerald N. Flerchinger \\ USDA-ARS \\ Haley Wicklein \\ University of New Hampshire \\ Katharine Hayhoe \\ Texas Tech University \\ See next page for additional authors
}

Follow this and additional works at: https://digitalcommons.unl.edu/usdaarsfacpub

Part of the Agricultural Science Commons

Campbell, John L.; Ollinger, Scott V.; Flerchinger, Gerald N.; Wicklein, Haley; Hayhoe, Katharine; and Bailey, Amey S., "Past and projected future changes in snowpack and soil frost at the Hubbard Brook Experimental Forest, New Hampshire, USA" (2011). Publications from USDA-ARS / UNL Faculty. 557. https://digitalcommons.unl.edu/usdaarsfacpub/557

This Article is brought to you for free and open access by the U.S. Department of Agriculture: Agricultural Research Service, Lincoln, Nebraska at DigitalCommons@University of Nebraska - Lincoln. It has been accepted for inclusion in Publications from USDA-ARS / UNL Faculty by an authorized administrator of DigitalCommons@University of Nebraska - Lincoln. 


\section{Authors}

John L. Campbell, Scott V. Ollinger, Gerald N. Flerchinger, Haley Wicklein, Katharine Hayhoe, and Amey S. Bailey 


\title{
Past and projected future changes in snowpack and soil frost at the Hubbard Brook Experimental Forest, New Hampshire, USA ${ }^{\dagger}$
}

\author{
John L. Campbell, ${ }^{1 *}$ Scott V. Ollinger, ${ }^{2}$ Gerald N. Flerchinger, ${ }^{3}$ Haley Wicklein, ${ }^{2}$ \\ Katharine Hayhoe ${ }^{4}$ and Amey S. Bailey ${ }^{5}$ \\ ${ }^{1}$ USDA Forest Service, Northern Research Station, Durham, NH 03824, USA \\ ${ }^{2}$ Complex Systems Research Center, University of New Hampshire, Durham, NH 03824, USA \\ ${ }^{3}$ USDA-ARS, Northwest Watershed Research Center, Boise, ID 83712, USA \\ ${ }^{4}$ Department of Geosciences, Texas Tech University, P.O. Box 41053, Lubbock, TX, USA \\ ${ }^{5}$ USDA Forest Service, Northern Research Station, North Woodstock, NH 03262, USA
}

\begin{abstract}
:
Long-term data from the Hubbard Brook Experimental Forest in New Hampshire show that air temperature has increased by about $1{ }^{\circ} \mathrm{C}$ over the last half century. The warmer climate has caused significant declines in snow depth, snow water equivalent and snow cover duration. Paradoxically, it has been suggested that warmer air temperatures may result in colder soils and more soil frost, as warming leads to a reduction in snow cover insulating soils during winter. Hubbard Brook has one of the longest records of direct field measurements of soil frost in the United States. Historical records show no long-term trends in maximum annual frost depth, which is possibly confounded by high interannual variability and infrequency of major soil frost events. As a complement to field measurements, soil frost can be modelled reliably using knowledge of the physics of energy and water transfer. We simulated soil freezing and thawing to the year 2100 using a soil energy and water balance model driven by statistically downscaled climate change projections from three atmosphere-ocean general circulation models under two emission scenarios. Results indicated no major changes in maximum annual frost depth and only a slight increase in number of freeze-thaw events. The most important change suggested by the model is a decline in the number of days with soil frost, stemming from a concurrent decline in the number of snow-covered days. This shortening of the frost-covered period has important implications for forest ecosystem processes such as tree phenology and growth, hydrological flowpaths during winter, and biogeochemical processes in soil. Published in 2010 by John Wiley \& Sons, Ltd.
\end{abstract}

KEY WORDS air temperature; climate change; general circulation model; precipitation; snow; soil frost

Received 17 July 2009; Accepted 22 February 2010

\section{INTRODUCTION}

Soil freezing is an important below-ground perturbation, having implications for the hydrology, biology and chemistry of ecosystems. Seasonally frozen ground is a widespread phenomenon, occurring over approximately $55 \%$ of the exposed land surface in the Northern Hemisphere (Zhang et al., 2004). Soil frost is often considered problematic, and the heaving associated with it can have adverse effects, such as uplifting planted seedlings and compromising the integrity of roads and structures. However, there are also benefits of frozen soil, for example it can improve accessibility and minimize disturbance during logging operations. In forest ecosystems, results from long-term observations and shorter-term experiments have shown that soil freezing can have a profound effect on ecosystem processes by damaging fine roots (Tierney et al., 2001; Cleavitt et al., 2008) and altering

\footnotetext{
* Correspondence to: John L. Campbell, USDA Forest Service, Northern Research Station, Durham, NH 03824, USA.

E-mail: jlcampbell@fs.fed.us

${ }^{\dagger}$ This article is a US Government work and is in the public domain in the USA.
}

litter decomposition (Sulkava and Huhta, 2003), nutrient leaching (Boutin and Robitaille, 1994; Fitzhugh et al., 2001; Fitzhugh et al., 2003) and trace gas fluxes (Groffman et al., 2006). Additionally, soil frost can alter hydrologic flowpaths, particularly in agricultural areas where hard, impenetrable 'concrete' frost forms (Shanley and Chalmers, 1999; Iwata et al., 2008).

Because soil freezing is controlled by meteorological variables (e.g. temperature, snow depth, soil moisture), future changes in climate may alter the depth and duration of frozen ground. Recent climate projections for the northeastern United States indicate that air temperatures may increase by $2 \cdot 1-5 \cdot 3^{\circ} \mathrm{C}$ during this century, depending on both the models and emission scenarios used (Hayhoe et al., 2008). While precipitation is more uncertain, projections indicate that winter precipitation is likely to increase by $12-30 \%$ with a greater proportion falling as rain rather than snow. These changes in climate are expected to decrease snow pack depth and snow cover duration. Paradoxically, it has been suggested that warmer air temperatures in the future may result in colder soil temperatures (and more soil frost) as there will be less snow cover insulating soils during winter (Isard and 
Schaetzl, 1998). This hypothesis is supported by snow depth manipulation experiments, which have shown that frost depth increases when snow is removed (Boutin and Robitaille, 1994; Groffman et al., 2001; Decker et al., 2003). However, in all of these experiments, snow depth was altered in the absence of warmer air temperatures, raising questions about how well these studies represent conditions associated with actual climate change (Henry, 2008).

Despite the important role of soil frost events in forest ecosystems, there has been little research on how soil freezing is affected by climate change. It is difficult to evaluate long-term trends in soil frost because available records are sparse and the methods used to measure soil frost are not always reliable (see review by French et al., 2006). Soil temperature is often used to approximate frost depth; however, subtle changes in temperature with depth make it difficult to interpolate the location of the frost line, and solute concentrations and water content can influence soil freezing (Banin and Anderson, 1974; Marion, 1995). Consequently, routine measurements of soil frost are exceedingly rare. One of the longest field records of soil frost comes from the Hubbard Brook Experimental Forest (HBEF) in New Hampshire, where technicians have made manual, tactile frost depth measurements consistently since 1956 (Bailey et al., 2003).

Soil freezing can also be modelled using knowledge of the physical processes affecting snowpack formation, surface heat exchange and freeze-thaw properties of soil water (DeGaetano et al., 1997; Kennedy and Sharrot, 1998; Lin and McCool, 2006). Development of soil freezing modelling capabilities at ecosystem research sites could open the door for retrospective analyses of ecological responses to wintertime soil conditions. These models can also be run with climate projections from statistically downscaled atmosphere-ocean general circulation model (AOGCM) output (Plummer et al., 2006; Hayhoe et al., 2007) to provide an indication of how soil frost might respond to future changes in climate (Venäläinen et al., 2001; Henry, 2008). Here, we used long-term data from the HBEF to: (1) examine historical trends in winter climate, snow and soil frost; (2) evaluate the accuracy of soil frost predictions from a soil water and energy balance model and (3) test the hypothesis that future climate change will lead to colder soils and increased soil frost depth due to decreasing snow cover.

\section{METHODS}

\section{Study site}

The HBEF $\left(43^{\circ} 56^{\prime} \mathrm{N}, 71^{\circ} 45^{\prime} \mathrm{W}\right)$ is a 3160 -ha bowlshaped valley in the White Mountain National Forest in central New Hampshire (Figure 1). Elevations range from $222 \mathrm{~m}$, where Hubbard Brook crosses the eastern boundary of the Experimental Forest, to $1015 \mathrm{~m}$ on Mt Kineo on the southwest rim of the basin. The climate is cool, humid and continental with average monthly air temperatures ranging from $-9^{\circ} \mathrm{C}$ in January to $18^{\circ} \mathrm{C}$ in July. Average annual precipitation is $1400 \mathrm{~mm}$ and is distributed fairly evenly throughout the year. A snowpack usually persists from late December until mid-April, with a peak depth in March. Vegetation is predominantly northern hardwood (Fagus grandifolia Ehrh., Acer saccharum Marsh., Betula alleghaniensis Britt.) with coniferous species (Picea rubens Sarg., Abies balsamea (L.) Mill.) occurring at higher elevations and on steeper slopes. Spodosols are the dominant soil type; Typic Haplorthods derived from glacial basal till. They have a sandy loamy texture and are well drained and shallow, with bedrock occurring at a depth of 1-2 m.

\section{Field measurements}

Snowpack measurements have been made weekly at the HBEF (stations 1-22) for various time periods since 1956; however, only stations 2 and 17 have continuous long-term records (52 and 42 years, respectively).

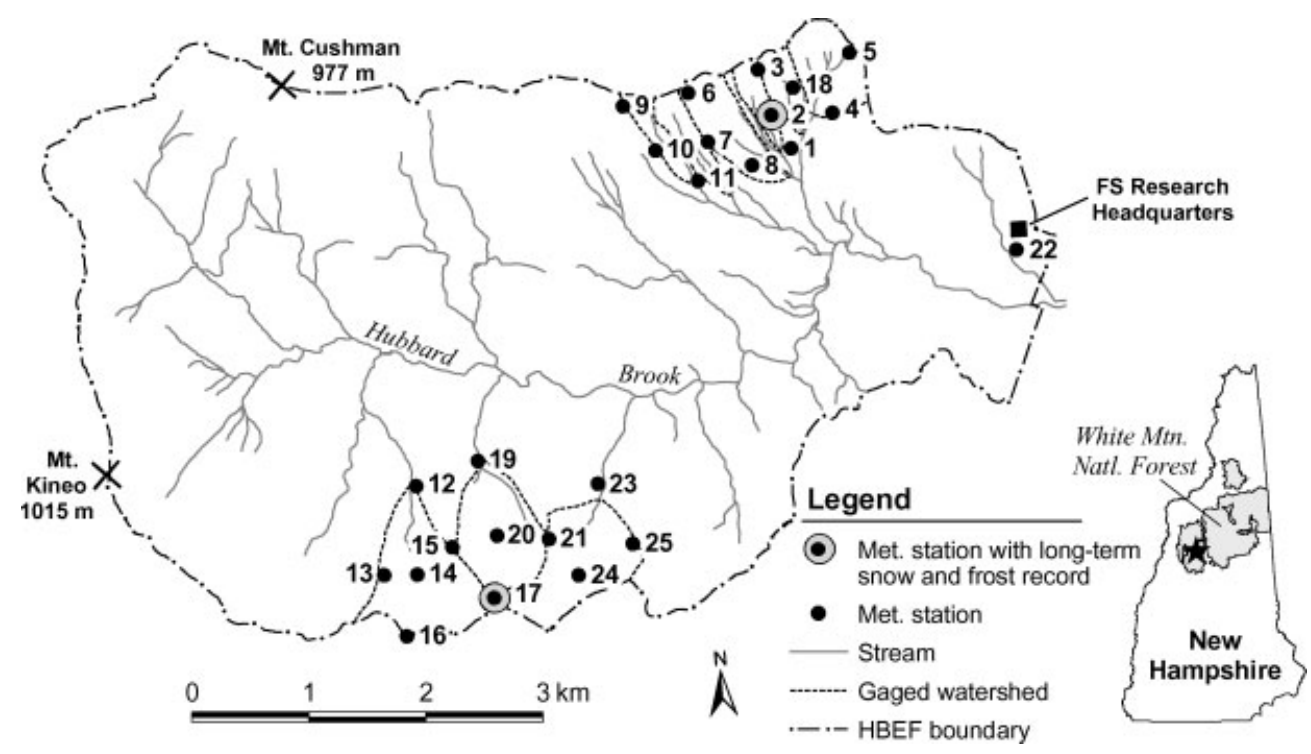

Figure 1. Site map of the Hubbard Brook Experimental Forest showing the network of numbered hydrometeorological stations 
Snow depth and snow water equivalent (SWE) are measured using standard methods (Soil Conservation Service, 1984) at 'snow courses' that are associated with hydrometeorological stations and are numbered accordingly (Figure 1). The snow courses are located under the forest canopy far enough away from rain gage clearings so that the edge effects are negligible. A 'snow course' consists of a transect of 10 points spaced at 2-m intervals. Each week, snow depth is recorded at each point, and a core of the snowpack is collected and weighed to determine SWE. The following week, an undisturbed parallel transect, 2-m from the previous transect, is used. In cases where a snow sampling point falls on an obstruction such as a tree or boulder, the measurement is made at a representative adjacent location where snow depth is not greatly affected by the obstruction (e.g. not in a tree well). Snow measurements begin when at least $2.54 \mathrm{~cm}$ (1 inch) of snow falls and remains on the ground, and end when the snowpack melts.

Manual measurements of soil frost are made weekly at a single point adjacent to snow courses (stations 2, $9,17,19,22)$. The longest records are from stations 2 and 17 (47 and 38 years, respectively) where frost depth has been measured every winter except 1965-1969 and 1973. The same method of measurement has been used consistently over the entire record at all sites. Field technicians probe through the snowpack with a pole. If the ground feels frozen they dig a snow pit, exposing the surface of the forest floor. A hatchet is used to cut through the frozen soil and the frost line is determined by tactile estimation. Frost depth values reported refer to the distance between the surface of the forest floor and the maximum depth of frozen soil.

Air temperature and precipitation are measured at a number of hydrometeorological station clearings (Figure 1). Since the inception of the HBEF in the mid-1950s, air temperature has been measured with hygrothermographs housed in standard shelters (Stevenson screens). Air temperature has been measured at seven locations, four of which have long-term records (stations 1, 6, 14 and 22 have 52, 47, 43 and 51 years of data, respectively). Precipitation at the HBEF is measured with a network of 25 rain gages distributed throughout the area of the experimental watersheds (Figure 1). Seven are weighing rain gages, which record precipitation volume continuously, whereas the others are standard gages that are measured weekly. Daily precipitation for a standard gage is determined by prorating its weekly total using daily totals from the nearest recording gages. Rain gages are installed $2.5 \mathrm{~m}$ off the ground to remain above the deepest snow, and have Alter shields to reduce wind effects. During winter, anti-freeze is added to the gages to melt new snow.

In addition to temperature and precipitation, field measurements of solar radiation and wind were needed for model input. These climate observations are used to define heat and water fluxes into the system. Solar radiation and wind have been measured at the HBEF Headquarters building (Figure 1) following protocols described by Bailey et al. (2003). Measurements are made in a clearing unobstructed by topographic features. The solar radiation sensor is mounted at a height of $2.5 \mathrm{~m}$ off the ground. Before 1981, solar radiation was measured with a bimetal recording pyranograph (actinometer). Since that time, a silicon cell pyranometer has provided hourly data. The older model pyranograph is still used as backup and provides comparable data. Wind speed is measured with an anemometer mounted $3 \mathrm{~m}$ off the ground. Wind data were recorded continuously with a strip chart until 1981 when the weather station at headquarters was replaced with an automated datalogging system.

\section{Model description}

Soil frost was simulated using the simultaneous heat and water (SHAW) model (Flerchinger and Saxton, 1989). The model was developed specifically for simulating soil freezing and thawing, but has been used in a variety of other applications including studies of snowpack accumulation and snowmelt (Flerchinger et al., 1994; Flerchinger et al., 1996), soil temperature and moisture, (Flerchinger et al., 1998; Hymer et al., 2000; Flerchinger and Hardegree, 2004; Flerchinger et al., 2006) and evapotranspiration (Flerchinger and Pierson, 1991; Preston and McBride, 2004). SHAW simulates heat and water transfer within a one-dimensional profile extending from the top of the forest canopy to a user-defined, lower soil boundary layer. An energy balance approach is used, whereby interrelated transfers of heat, liquid water, water vapour and solutes occur across ecosystem layers including the forest canopy, snowpack, litter and soil strata. The direction, quantity and transformation of energy flow across layers are determined by energy balance equations based on the law of conservation of energy. Major processes captured by the model include transpiration through a multi-species canopy, snowpack accumulation and melt, soil evaporation, fluxes of soil water and solutes, and detailed characterization of soil freezing and thawing. In the model, a soil layer is considered frozen if it contains ice. Ice content for each layer is determined by the soil moisture content and temperature, taking the freezing point depression into account. Frost depth is computed by interpolating ice content over depth within the soil layer of maximum frost. Frost depths are reported as the distance from the soil surface to the bottom of the frost layer and do not account for top-down thawing.

Required SHAW model parameters include those related to the site, vegetation, litter layer and soil (Table I). Climate inputs for the model consist of daily minimum and maximum air temperature, dew point temperature, total daily wind run $(\mathrm{km})$, precipitation and average solar radiation. A sensitivity analysis conducted by Flerchinger (1991) indicated that soil freezing simulations from the model are most sensitive to air temperature and snow depth. Simulated frost depth was also potentially sensitive to the slope, litter layer thickness, soil thermal conductivity, soil bulk density and surface roughness. Accuracy of the measurements made herein for 
Table I. SHAW model parameters

\begin{tabular}{|c|c|c|c|c|c|c|c|c|c|}
\hline Parameter & Unit & & & & Value & & & & Reference \\
\hline \multicolumn{10}{|l|}{ Site } \\
\hline Latitude & deg., min. & & & & 43,57 & & & & \\
\hline Longitude & deg., min. & & & & $-71,44$ & & & & \\
\hline Elevation & $\mathrm{m}$ & & & & 561 & & & & \\
\hline Slope & $\%$ & & & & $33 \cdot 5$ & & & & \\
\hline Aspect & Deg. & & & & 149 & & & & \\
\hline Time of solar noon & $\mathrm{h}$ & & & & $11 \cdot 8$ & & & & \\
\hline Measurement height & $\mathrm{m}$ & & & & 22 & & & & \\
\hline \multicolumn{10}{|l|}{ Vegetation } \\
\hline $\begin{array}{l}\text { No. of species } \\
\text { simulated }\end{array}$ & & & & & 1 & & & & \\
\hline Height of species & $\mathrm{m}$ & & & & 20 & & & & $\begin{array}{l}\text { Bormann and } \\
\text { Likens, } 1979\end{array}$ \\
\hline Leaf dimension & $\mathrm{m}$ & & & & $0 \cdot 10$ & & & & Federer, 2002 \\
\hline Dry plant biomass & $\mathrm{kg} / \mathrm{m}^{2}$ & & & & 24 & & & & Siccama et al., 2007 \\
\hline Leaf Area Index & $\mathrm{m}^{2} / \mathrm{m}^{2}$ & & & & $5 \cdot 0$ & & & & Rhoads et al., 2004 \\
\hline $\begin{array}{l}\text { Effective rooting } \\
\text { depth }\end{array}$ & $\mathrm{m}$ & & & & 0.73 & & & & Federer, 2002 \\
\hline Leaf albedo & & & & & $0 \cdot 25$ & & & & $\begin{array}{l}\text { Birkebak and } \\
\text { Birkebak, } 1964\end{array}$ \\
\hline $\begin{array}{l}\text { Transpiration } \\
\text { threshold }\end{array}$ & ${ }^{\circ} \mathrm{C}$ & & & & 0 & & & & \\
\hline $\begin{array}{l}\text { Min. stomatal } \\
\text { resistance }\end{array}$ & $\mathrm{s} / \mathrm{m}$ & & & & 350 & & & & Federer, 1977 \\
\hline Resistance exponent & & & & & 5 & & & & Flerchinger, 2000 \\
\hline $\begin{array}{l}\text { Crit. leaf water } \\
\text { potential }\end{array}$ & $\mathrm{m}$ & & & & -150 & & & & Federer, 1977 \\
\hline Leaf resistance & $\mathrm{kg} / \mathrm{m}^{3} / \mathrm{s}$ & & & & $8.0 \times 10^{5}$ & & & & Federer, 2002 \\
\hline Root resistance & $\mathrm{kg} / \mathrm{m}^{3} / \mathrm{s}$ & & & & $1.6 \times 10^{6}$ & & & & Federer, 2002 \\
\hline \multicolumn{10}{|l|}{ Litter } \\
\hline No. litter nodes & & & & & 1 & & & & \\
\hline Litter cover & $\%$ & & & & 100 & & & & \\
\hline Albedo of litter & & & & & $0 \cdot 16$ & & & & Federer, 1971 \\
\hline Dry mass of litter & $\mathrm{kg} / \mathrm{ha}$ & & & & 1200 & & & & Federer, 1983 \\
\hline Thickness of litter & $\mathrm{cm}$ & & & & 1 & & & & Federer, 1982 \\
\hline Litter resistance & $\mathrm{s} / \mathrm{m}$ & & & & 50000 & & & & Flerchinger, 2000 \\
\hline \multicolumn{10}{|l|}{ Soil } \\
\hline No. of soil nodes & & & & & 7 & & & & \\
\hline Air entry potential & $\mathrm{m}$ & & & & $-0 \cdot 2$ & & & & $\begin{array}{l}\text { Clapp and } \\
\text { Hornberger, } 1978\end{array}$ \\
\hline $\mathrm{K}_{\mathrm{sat}}$ & $\mathrm{cm} / \mathrm{hr}$ & & & & $2 \cdot 5$ & & & & Hong et al., 2005 \\
\hline Sand/Silt/Clay & $\%$ & & & & $60 / 30 / 10$ & & & & $\begin{array}{l}\text { Lovett and Reuth, } \\
1999\end{array}$ \\
\hline Soil layer & & 1 & 2 & 3 & 4 & 5 & 6 & 7 & \\
\hline Node depth & $\mathrm{m}$ & 0.04 & $0 \cdot 11$ & $0 \cdot 18$ & $0 \cdot 30$ & 0.47 & 0.65 & 0.82 & Federer, 2002 \\
\hline Pore size & & 6 & $3 \cdot 5$ & 7 & 5 & 5 & 5 & 5 & Federer, 2002 \\
\hline \multicolumn{10}{|l|}{ distribution index } \\
\hline Bulk density & $\mathrm{kg} / \mathrm{m}^{3}$ & 130 & 1034 & 769 & 848 & 954 & 1034 & 1405 & Federer, 2002 \\
\hline $\begin{array}{l}\text { Sat. vol. moisture } \\
\text { content }\end{array}$ & vol./vol. & 0.90 & $0 \cdot 61$ & $0 \cdot 71$ & 0.68 & 0.64 & 0.61 & 0.47 & Federer, 2002 \\
\hline Organic matter & $\%$ & 70 & 5 & 14 & 14 & 8 & 8 & 4 & $\begin{array}{l}\text { Johnson et al. } \\
\text { 1991a,b }\end{array}$ \\
\hline
\end{tabular}

slope, litter layer thickness and soil bulk density were well within the perturbations explored by Flerchinger (1991), and thermal conductivity can be accurately estimated within the model from soil texture and density. Input surface roughness is applicable only when no plant cover is present as the roughness parameters are estimated within the model for plant cover. Soil freezing simulations were reportedly not very sensitive to solar radiation because solar radiation is typically minimal during the freeze/thaw season and because of the offsetting influence of simulated cloud cover and incoming longwave radiation.

\section{Model application}

To allow validation against the measured soil frost record at Hubbard Brook, the SHAW model was run for station 2 using climate data for the last 30 years (1979 through 2008). While some climate data date back to the mid-1950s (e.g. temperature and precipitation), we focused on the last 30 years of measurement based on 
Table II. Description and definition of model performance measures

\begin{tabular}{|c|c|c|c|}
\hline Measure & Abbreviation & Description & Mathematical definition \\
\hline Mean absolute error & MAE & $\begin{array}{l}\text { Average of the absolute difference between } \\
\text { simulated and observed values }\end{array}$ & $\frac{1}{N} \sum_{i=1}^{N}\left|P_{i}-O_{i}\right|$ \\
\hline $\begin{array}{l}\text { Mean absolute error } \\
\text { percent }\end{array}$ & MAEP & $\begin{array}{l}\text { Average absolute error expressed as a percent } \\
\text { of the measured mean }\end{array}$ & $\left(\frac{M A E}{\bar{O}}\right) \cdot 100$ \\
\hline Mean bias error & MBE & $\begin{array}{l}\text { Average of the difference between simulated } \\
\text { and observed values }\end{array}$ & $\frac{1}{N} \sum_{i=1}^{N}\left(P_{i}-O_{i}\right)$ \\
\hline Mean bias error percent & MBEP & $\begin{array}{l}\text { Average mean bias error expressed as a } \\
\text { percent of the measured mean }\end{array}$ & $\left(\frac{M B E}{\bar{O}}\right) \cdot 100$ \\
\hline
\end{tabular}

${ }^{\text {a }} O$, observed value; $P$, simulated value; $\bar{O}$, mean of observed values; $N$, number of observations.

the completeness of all the climate data needed to run the model (i.e. solar radiation, wind, relative humidity). Nearly all climate inputs were available directly from site-level measurements, with the exception of dew point temperatures which were calculated using vapour pressure in a modified version of Tetens' equation (Tetens, 1930). Model performance was evaluated through the comparison of predicted and observed soil frost with correlation coefficients, mean absolute error and mean bias error (MBE) expressed in real values and as a percent. Mean absolute error is the average of the absolute difference between simulated and observed values and is therefore a positive value, whereas MBE is the average of the difference between simulated and observed values and can be negative or positive (Table II).

For simulation of future soil freezing and thawing, we used climate change projections generated for the northeastern United States by Hayhoe et al. $(2007,2008)$ using three-coupled AOGCMs and two scenarios of future emissions. The AOGCMs used were the Geophysical Fluid Dynamics Laboratory Model (GFDL, Delworth et al., 2006), the Hadley Centre Coupled Model, version 3 (HadCM3, Pope et al., 2000), and the Parallel Climate Model (PCM, Washington et al., 2000). All AOGCM model output was available from the Intergovernmental Panel on Climate Change Fourth Assessment Report database (IPCC, 2007). Each model was run under two future greenhouse gas emission scenarios (A1FI and B1), for a total of six climate simulations. The A1FI (higher) and B1 (lower) emissions scenarios correspond to potential atmospheric $\mathrm{CO}_{2}$ concentrations of 970 and $550 \mathrm{ppm}$, respectively, by 2100 (Nakicenovic et al., 2001). This is roughly equivalent to more than a tripling (A1FI) and doubling (B1) of atmospheric $\mathrm{CO}_{2}$ concentrations relative to pre-industrial levels. The resulting monthly ensemble AOGCM forecasts were bias corrected, downscaled to $1 / 8^{\circ}$ horizontal resolution, and disaggregated to a daily time interval (Hayhoe et al., 2007). For the present study, climate projections were extracted for the coordinates that best match the location of Hubbard Brook. Simulated precipitation from all three models was approximately $20 \%$ lower than measured values for the period 1979-2008, likely due to local effects of mountainous topography. Following Ollinger et al. (2008), projected precipitation amounts for Hubbard Brook (HB) were scaled upwards by $20 \%$ to account for this discrepancy.

SHAW simulations were run on a daily time step from 2009 through the end of the 21 st century using the downscaled climate simulations. Because there is more uncertainty in how future precipitation will change compared to future air temperature (Hayhoe et al., 2007), we conducted an additional set of SHAW model simulations using detrended precipitation. Future winter precipitation for each scenario was detrended by calculating the Sen slope (as described in the next section) for 2009-2099 and decreasing the daily winter (Dec-Mar) precipitation values accordingly. The model was then rerun using these new daily precipitation input values, while keeping all other climate input and model parameters the same. This allowed us to determine the extent to which changes in predicted soil and snowpack conditions were driven by changes in precipitation versus changes in temperature.

\section{Statistical trend analysis}

Temporal past and future trends in climate and soil frost at Hubbard Brook were evaluated using the non-parametric Mann-Kendall test, which is commonly applied to analyses of long-term hydrometeorological data (Kendall, 1938; Helsel and Hirsch, 1992). One of the advantages of this test is that it is rank-based, making it suitable for non-normally distributed data, data containing outliers and non-linear trends such as those often encountered in long-term hydrometeorological research. A $p$ value of $<0.10$ was used to indicate statistical significance. The slope for each trend was calculated as the median of all possible pair-wise slopes (Sen, 1968), and is referred to here as the Sen slope. The percent change over the period of record was calculated by multiplying the Sen slope by the number of years that data were collected. Long-term trends were only analysed at stations with more than 40 years of data, which is the minimum sample size suggested for the Mann-Kendall normal approximation test (Gilbert, 1987). All annual values reported in this manuscript are based on October 1 water year (e.g. WY 1993 is from 1 October 1992 through 30 September 1993). The unit cm-days used throughout this article refers to the annual sum of daily values and is therefore a cumulative metric of snow depth, SWE and soil frost 


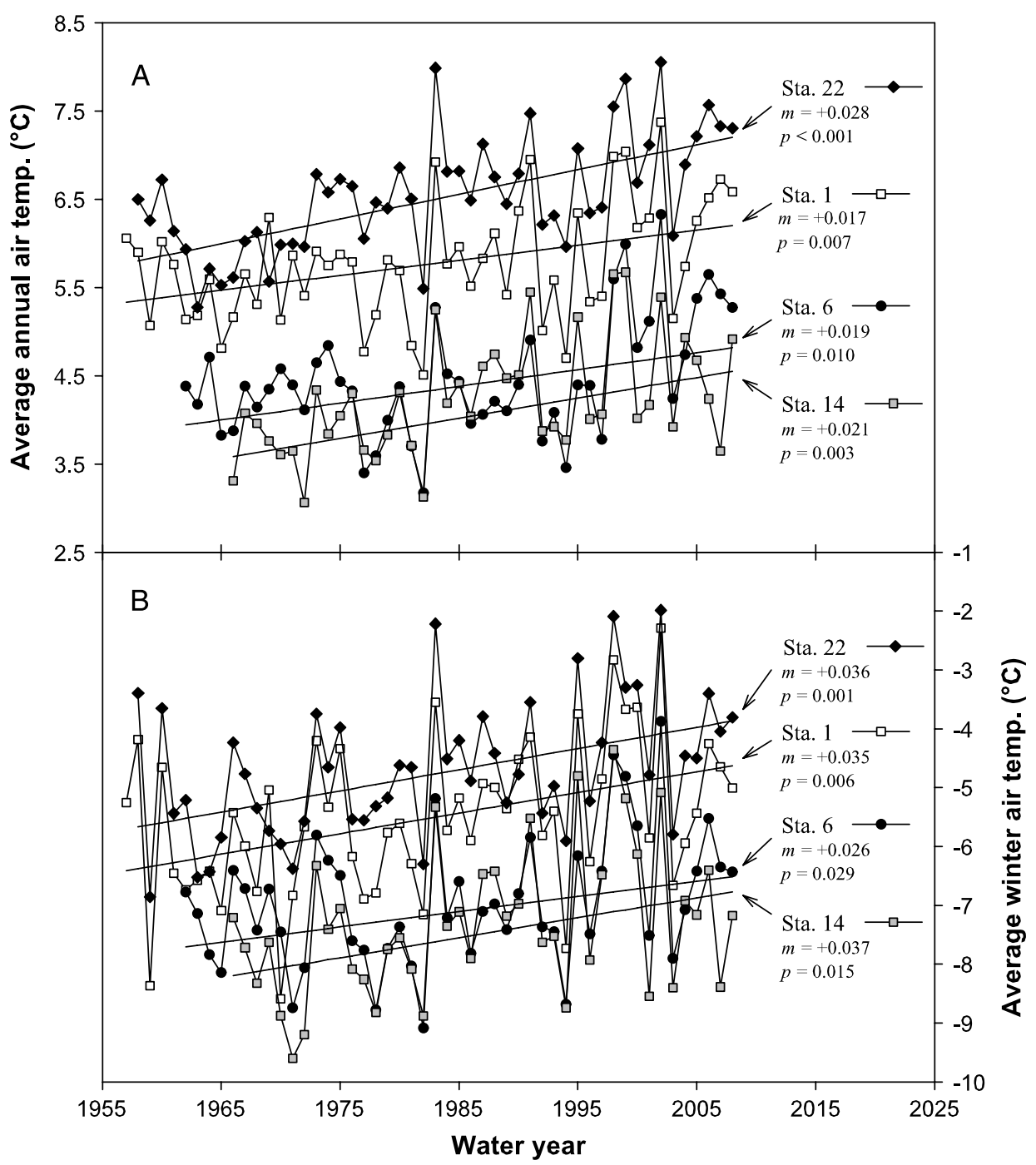

Figure 2. Long-term trends in average annual (A) and winter (B) air temperature at stations 1, 6, 14 and 22 (m = Sen slope). Winter is defined as December through March

depth. The number of snow cover events is defined as the number of times that the snowpack forms and dissipates during the year. The number of freeze-thaw events refers to the number of times that the soil freezes and completely melts during the year.

\section{RESULTS}

\section{Historical climate trends}

Average annual air temperature increased significantly for various periods of measurement at the four stations evaluated, with Sen slopes ranging from $+0 \cdot 017$ to $+0.028^{\circ} \mathrm{C}$ per year (Figure 2A). The smallest increase was at station 1 amounting to $0.9^{\circ} \mathrm{C}$ over 52 years of measurement and the greatest increase was at station 22 amounting to $1.4^{\circ} \mathrm{C}$ over 51 years. Increases in winter (December through March) temperature were also significant at all four weather stations. Winter temperature changed to a greater degree than mean annual temperature, with slopes ranging from +0.029 to $+0.036{ }^{\circ} \mathrm{C}$ per year.
Twelve of the seventeen rain gages evaluated showed significant increases in annual precipitation over the full period of their measurement records (Table III). Significant increases occurred at all rain gages with 48 or more years of data. The other rain gages evaluated (rain gages 9-17) had fewer years of data (43 to 44 years) and did not all show significant trends in precipitation, although all had positive Sen slopes. Increasing trends at stations with the longest records were influenced by an extended period of drought in the 1960s, although similar low precipitation years are found throughout the record (e.g. 1957, 1988, 1995, 2001; Figure 3). Significant precipitation increases ranged from $+0.67 \mathrm{~cm}$ per year at station $6(+32 \mathrm{~cm}$ total over 48 years of measurement) to $+0.37 \mathrm{~cm}$ per year at station $11(+16 \mathrm{~cm}$ total over 44 years of measurement). If the same time period (1966-2008) is evaluated at all rain gages, all stations still show increases in precipitation, but only 6 of the 17 stations show significant increases and the stations that show significant increases do not appear to be influenced by position in the basin. Winter precipitation comprised approximately one-third of annual precipitation. There 
Table III. Meteorological station descriptions, average annual precipitation $(\mathrm{cm})$ and change in annual and winter (December through March) precipitation per year $(\mathrm{cm})$. Sen slope $p$ values are shown in parentheses and significant trends $(\alpha=0 \cdot 10)$ are indicated in boldface

\begin{tabular}{|c|c|c|c|c|c|c|c|c|}
\hline Station & $\begin{array}{l}\text { Elevation } \\
\quad(\mathrm{m})\end{array}$ & $\begin{array}{l}\text { Aspect }^{\mathrm{a}} \\
\text { (deg.) }\end{array}$ & $\begin{array}{l}\text { Initial Water } \\
\text { year }\end{array}$ & $\begin{array}{c}\text { Tot. Water } \\
\text { years. }\end{array}$ & $\begin{array}{l}\text { Avg. annual } \\
\text { precipitation }\end{array}$ & $\begin{array}{c}\Delta \text { annual } \\
\text { precip/year ( } p \text { value })\end{array}$ & $\begin{array}{l}\text { Avg. winter } \\
\text { precipitation }\end{array}$ & $\begin{array}{c}\Delta \text { winter } \\
\text { precip/year }(p \text { value })\end{array}$ \\
\hline 1 & 490 & 130 & 1957 & 52 & 134 & $+0.54(0.005)$ & 41 & $+0 \cdot 01(0.950)$ \\
\hline 2 & 560 & 170 & 1957 & 52 & 136 & $+0.62(0.003)$ & 42 & $+0.05(0.473)$ \\
\hline 3 & 720 & 171 & 1957 & 52 & 131 & $+0.45(0.008)$ & 39 & $+0 \cdot 01(0.900)$ \\
\hline 4 & 560 & 261 & 1957 & 52 & 133 & $+0.59(0.003)$ & 41 & $+0.05(0.453)$ \\
\hline 5 & 670 & 204 & 1959 & 50 & 137 & $+0.42(0.024)$ & 43 & $0.00(0.967)$ \\
\hline 6 & 750 & 130 & 1961 & 48 & 137 & $+0.67(0.002)$ & 42 & $+0 \cdot 07(0 \cdot 307)$ \\
\hline 7 & 600 & 176 & 1961 & 48 & 138 & $+0.57(0.002)$ & 42 & $+0 \cdot 05(0.472)$ \\
\hline 8 & 510 & 106 & 1961 & 48 & 138 & $+0.62(0.001)$ & 42 & $+0 \cdot 07(0.419)$ \\
\hline 9 & 760 & 169 & 1965 & 44 & 143 & $+0 \cdot 35(0.103)$ & 44 & $-0.09(0.270)$ \\
\hline 10 & 670 & 141 & 1965 & 44 & 146 & $+0.45(0.038)$ & 46 & $-0.09(0.327)$ \\
\hline 11 & 550 & 173 & 1965 & 44 & 141 & $+0 \cdot 37(0 \cdot 099)$ & 43 & $-0 \cdot 07(0 \cdot 347)$ \\
\hline 12 & 620 & 315 & 1966 & 43 & 146 & $+0.44(0.107)$ & 45 & $-0 \cdot 06(0.439)$ \\
\hline 13 & 770 & 15 & 1966 & 43 & 146 & $+0.45(0.044)$ & 44 & $-0 \cdot 04(0 \cdot 630)$ \\
\hline 14 & 730 & 343 & 1966 & 43 & 147 & $+0.43(0.072)$ & 45 & $-0 \cdot 12(0 \cdot 254)$ \\
\hline 15 & 770 & 309 & 1966 & 43 & 148 & $+0.35(0.194)$ & 46 & $-0 \cdot 16(0 \cdot 107)$ \\
\hline 16 & 860 & 243 & 1966 & 43 & 149 & $+0.38(0.202)$ & 47 & $-0.19(0.137)$ \\
\hline 17 & 890 & 63 & 1966 & 43 & 148 & $+0 \cdot 38(0 \cdot 202)$ & 47 & $-0 \cdot 17(0 \cdot 180)$ \\
\hline
\end{tabular}

${ }^{\text {a }}$ Degrees clockwise from north.

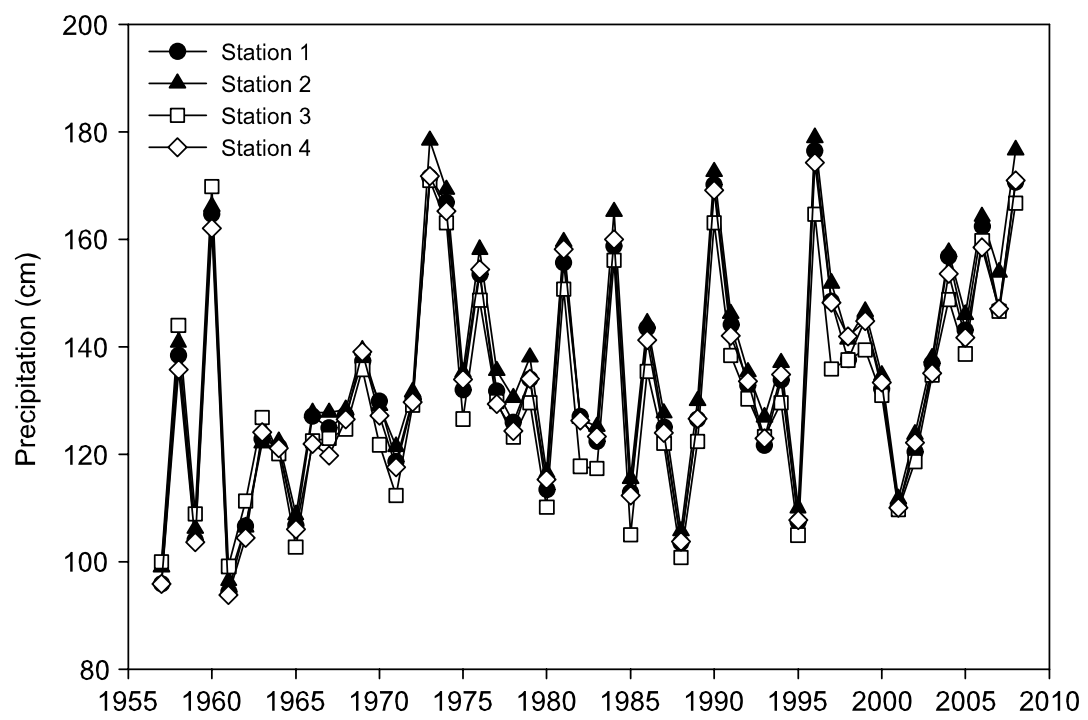

Figure 3. Annual precipitation $(\mathrm{cm})$ at the four stations with the longest records (52 years)

were no significant trends in winter (December through March) precipitation at any of the rain gages over the measurement period.

Changes in the snowpack were observed at both measurement locations (stations 2 and 17). Station 2, which has the longest record, showed significant declines in all snow metrics (Table IV). Maximum snow depth declined by $25 \mathrm{~cm}$, SWE declined by $7 \mathrm{~cm}$, and snow cover duration declined by 21 days over 53 years of measurement. At station 17 (43 years of data), only cumulative SWE showed significant declines; however, Sen slopes for all other snow metrics were negative.

Annual maximum frost depth showed no significant trends at station 2 or 17 (Figure 4) and there were no significant trends in the number of days with soil frost. At station 2, which is warmer and at a lower elevation than station 17 , soil frost was present during $62 \%$ of the years it was measured and reached a maximum depth of $26 \mathrm{~cm}$. At station 17, soil frost was present during $76 \%$ of the years and reached a maximum depth of $25 \mathrm{~cm}$. There was a strong positive relationship for annual maximum soil frost depth between stations 2 and $17\left(r^{2}=0.52\right.$, $p$ value $=0.000)$, with greater depths on average at the colder, higher elevation station 17.

\section{Model evaluation}

SHAW model results were evaluated by comparing predicted versus measured values for the period when adequate data were available (WY 1979 to 2008; Table V, Figure 5). The model captured a greater fraction of the variability in measured cumulative snowpack depth and cumulative SWE ( $r^{2}=0.83$ and 0.80 , respectively) 
Table IV. Measured annual means and change per year in snow metrics at station 2 (WY 1956-2008) and station 17 (WY 1966-2008). Sen slope $p$ values are shown in parentheses and significant trends $(\alpha=0 \cdot 10)$ are indicated in boldface

\begin{tabular}{|c|c|c|c|c|}
\hline \multirow[t]{2}{*}{ Item } & \multicolumn{2}{|c|}{ Station 2} & \multicolumn{2}{|c|}{ Station 17} \\
\hline & mean $(\mathrm{SD})$ & $\Delta /$ year ( $p$ value $)$ & mean (SD) & $\Delta$ /year ( $p$ value $)$ \\
\hline Maximum snow depth $(\mathrm{cm})$ & $72(25)$ & $-0 \cdot 48(0 \cdot 043)$ & $106(31)$ & $-0 \cdot 24(0 \cdot 586)$ \\
\hline Cumulative snow depth (cm-days) & $5067(2373)$ & $-60(0 \cdot 004)$ & 9363(3674) & $-74(0 \cdot 107)$ \\
\hline Maximum SWE (cm) & 19(7) & $-0 \cdot 14(0 \cdot 033)$ & $28(9)$ & $-0 \cdot 15(0 \cdot 201)$ \\
\hline Cumulative SWE (cm-days) & $1279(669)$ & $-15(0 \cdot 011)$ & 2398(997) & $-26(0 \cdot 024)$ \\
\hline Snow-covered days (days) & $119(22)$ & $-0 \cdot 39(0 \cdot 044)$ & 147(19) & $-0 \cdot 22(0 \cdot 384)$ \\
\hline
\end{tabular}

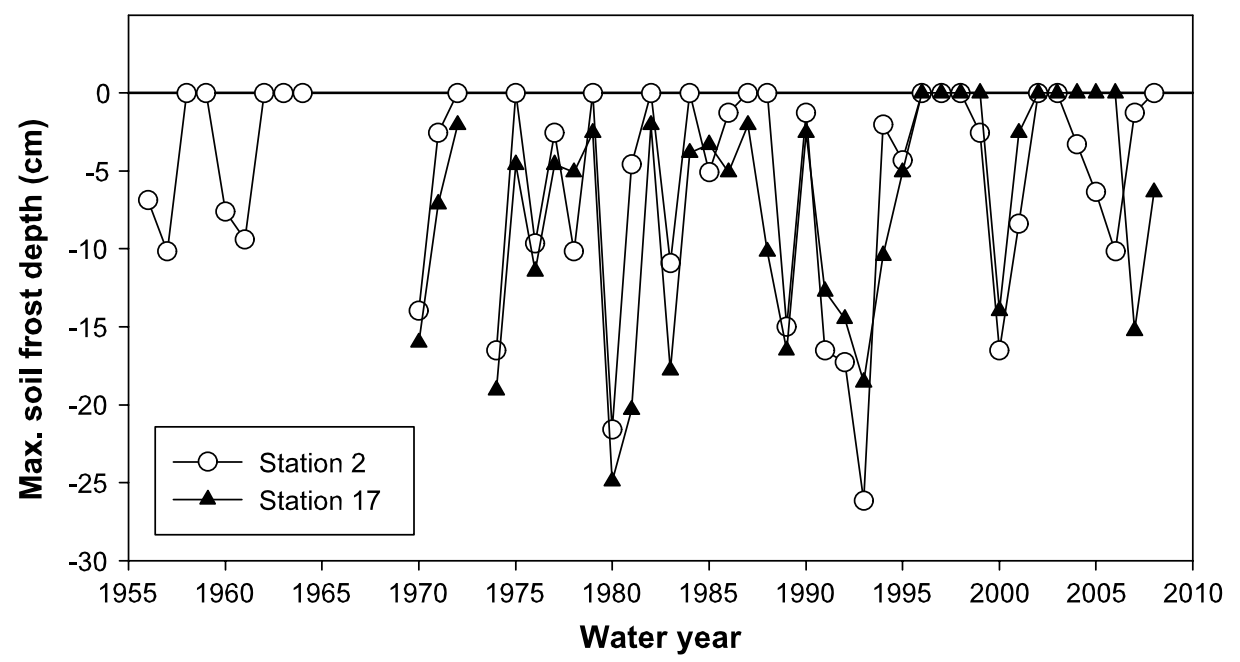

Figure 4. Maximum annual soil frost depth $(\mathrm{cm})$ measured at stations 2 and 17

Table V. Evaluation of model fit for WY 1979-2008 at station 2 for snow, snow water equivalent, and soil frost expressed as annual maximum values $(\mathrm{cm})$ and annual cumulative sum of daily values $(\mathrm{cm}$-days). The model was run using measured climate input values

\begin{tabular}{|c|c|c|c|c|c|c|c|}
\hline Item & $\begin{array}{c}\bar{O} \\
(\mathrm{SD})\end{array}$ & $\begin{array}{c}\bar{P} \\
(\mathrm{SD})\end{array}$ & $\begin{array}{c}\mathrm{r}^{2} \\
(p \text { value })\end{array}$ & MAE & MAEP & MBE & MBEP \\
\hline Maximum snow depth $(\mathrm{cm})$ & $65 \cdot 0(21 \cdot 9)$ & $69 \cdot 5(22 \cdot 3)$ & $0.52(0 \cdot 000)$ & 13 & 19 & 4 & 7 \\
\hline Cumulative snow depth (cm-days) & 4134(2220) & $3526(2059)$ & $0 \cdot 83(0 \cdot 000)$ & 919 & 22 & -608 & -15 \\
\hline Maximum SWE (cm) & $16 \cdot 5(6 \cdot 6)$ & $15 \cdot 5(6 \cdot 5)$ & $0.72(0 \cdot 000)$ & 3 & 19 & -1 & -6 \\
\hline Cumulative SWE (cm-days) & 1043(661) & $897(575)$ & $0.80(0 \cdot 000)$ & 255 & 24 & -146 & -14 \\
\hline Maximum soil frost depth $(\mathrm{cm})$ & $5 \cdot 8(7 \cdot 5)$ & $5 \cdot 4(6 \cdot 6)$ & $0 \cdot 47(0 \cdot 000)$ & 4 & 65 & 0 & -7 \\
\hline Cumulative soil frost (cm-days) & $227(352)$ & 261(394) & $0.48(0.000)$ & 182 & 80 & 34 & 15 \\
\hline
\end{tabular}

$\bar{O}$, mean annual observed value; $\bar{P}$, mean annual simulated value; $r^{2}$, coefficient of determination; MAE, mean absolute error; MAEP, mean absolute error percent; MBE, mean bias error; MBEP, mean bias error percent.

compared to maximum annual snow depth and maximum SWE $\left(r^{2}=0.52\right.$ and 0.72 , respectively). However, the mean absolute error percent for the cumulative snowpack depth and SWE (22 and 24\%, respectively) was greater than maximum annual snow depth and SWE (19\% for both). Predictions of soil frost showed greater disagreement with observations than did predictions of snowpack. The model accounted for slightly less than half of the variability in measured cumulative soil frost and annual maximum frost depth, with higher mean absolute error (65 and $80 \%$, respectively) compared to the snowpack measurements. For all the snowpack and soil frost measurements evaluated, the MBE ranged from -15 to $+15 \%$.

\section{Future climate trends}

Six climate projections developed for the HBEF were used as model input for future snowpack and soil frost simulations. These climate projections were developed by statistically downscaling AOGCM output. The climate projections showed significant increases in mean annual air temperature for all scenarios, ranging from 1.8 to $8 \cdot 2{ }^{\circ} \mathrm{C}$ for $2009-2099\left(0.02-0.09{ }^{\circ} \mathrm{C}\right.$ per year; Table VI). For all three models, the higher emissions $\mathrm{CO}_{2}$ scenarios $(\mathrm{A} 1 \mathrm{FI}=970 \mathrm{ppm}$ by 2100$)$ produced greater increases in temperature than the lower emissions scenario $(\mathrm{B} 1=$ 550 ppm by 2100). For each of the two $\mathrm{CO}_{2}$ scenarios, the HADCM3 model produced the greatest increase in temperature, the PCM model produced the least, and 

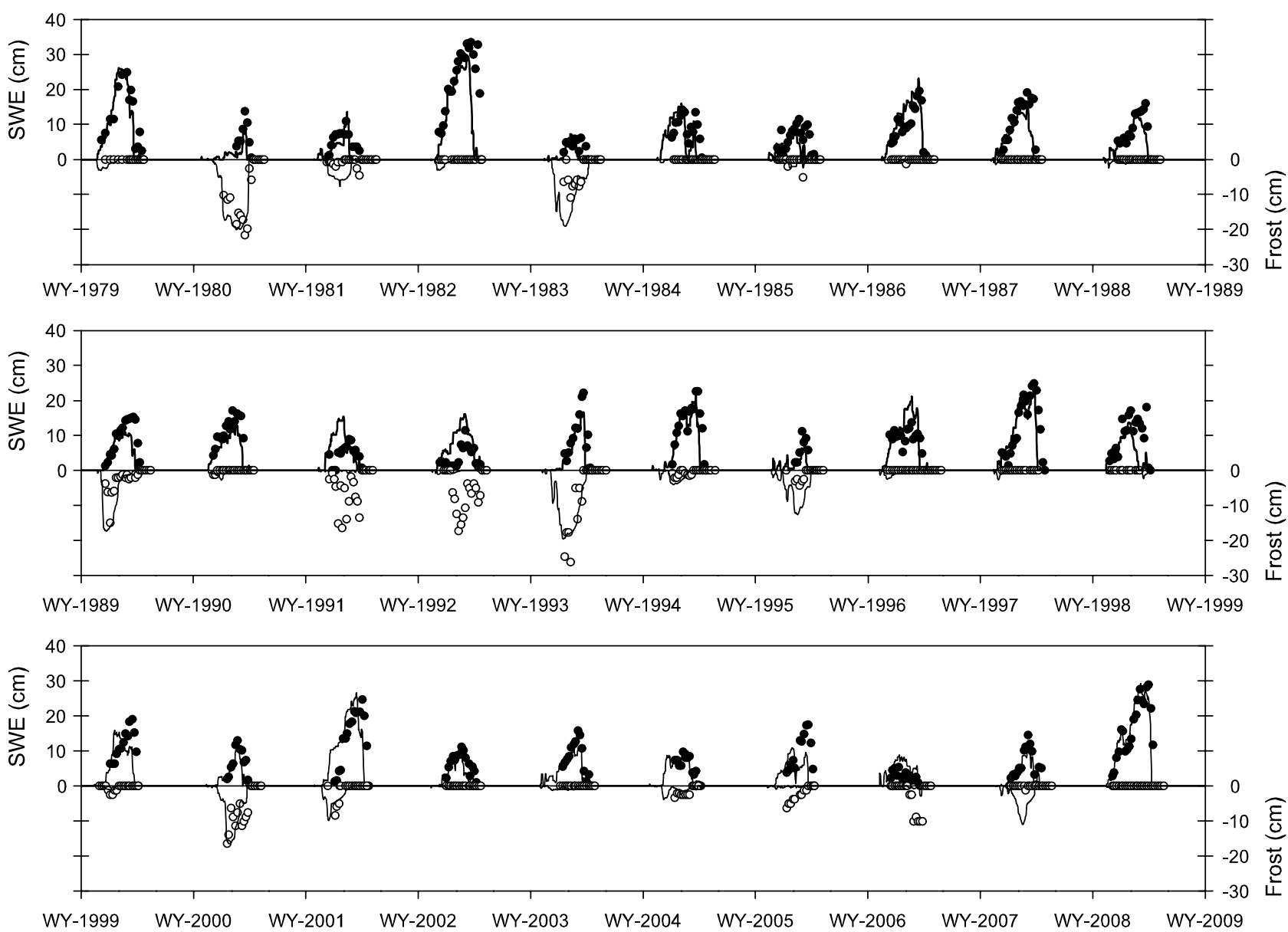

Figure 5. Comparison of modelled (solid lines) and measured snow water equivalent (solid circles) and soil frost depth (hollow circles) at station 2 for WY 1979-2008

the GFDL model was intermediate. Winter temperatures also increased significantly for all scenarios and had Sen slopes that were similar to those for annual temperatures. Predicted precipitation was more variable than air temperature, but increased under all scenarios. Four of the six scenarios showed significant increases in annual precipitation, ranging from 14 to $30 \mathrm{~cm}(0 \cdot 15-0.33 \mathrm{~cm}$ per year) or a 10 to $22 \%$ increase over the period from 2009 to 2099. The same four scenarios also showed significant increases in winter precipitation ranging from 6 to $20 \mathrm{~cm}(0 \cdot 07-0.22 \mathrm{~cm}$ per year) or a 14 to $40 \%$ increase for 2009-2099.

All snowpack metrics we investigated showed patterns that are consistent with declining future snowpack (Table VI). Predicted maximum annual snowpack depth decreased significantly in four of the six scenarios, amounting to a reduction of $31-47 \mathrm{~cm}$ from 2009 to $2099(0.34-0.52 \mathrm{~cm}$ per year) or $6-10 \mathrm{~cm} \mathrm{SWE}$ (0.07-0.11 cm per year). Cumulative snow depth and SWE also showed significant decreases in four of the six scenarios. Under all scenarios, snow cover duration decreased significantly from 2009 to 2099 and from 20 to 79 days $(0.22-0.87$ days per year), while the number of snow cover events increased significantly (by 2-3 events per year) under three of the six scenarios (Table VI).
Changes in projected future soil frost during 20092099 were less apparent than changes in projected snowpack. A significant change in projected maximum annual soil frost depth occurred in just one of the scenarios examined (GFDL B1) and showed a decline of $4.5 \mathrm{~cm}$ over 91 years $(0.05 \mathrm{~cm}$ per year; Table VI). Cumulative soil frost declined significantly under two scenarios, amounting to a 32 to $77 \%$ decrease in the mean for 2009-2099 ( 1.8 to $2.6 \mathrm{~cm}$-days per year). The number of days per year when soil frost was present decreased significantly in five of the six scenarios, ranging from 21 to 55 fewer days during 2009-2099 (0.23-0.60 days per year). The number of annual freeze-thaw events increased by $1-3$ events per year over the same period (Table VI). As a separate analysis, the model was run using detrended winter precipitation to evaluate whether projected changes in snow and soil frost were driven by changes in projected precipitation or changes in projected temperature (Table VII). While there were minor differences with respect to results shown in Table VI, the snowpack and soil frost projections resulting from detrended precipitation followed the same overall pattern as model runs conducted using the original AOGCM precipitation projections. 


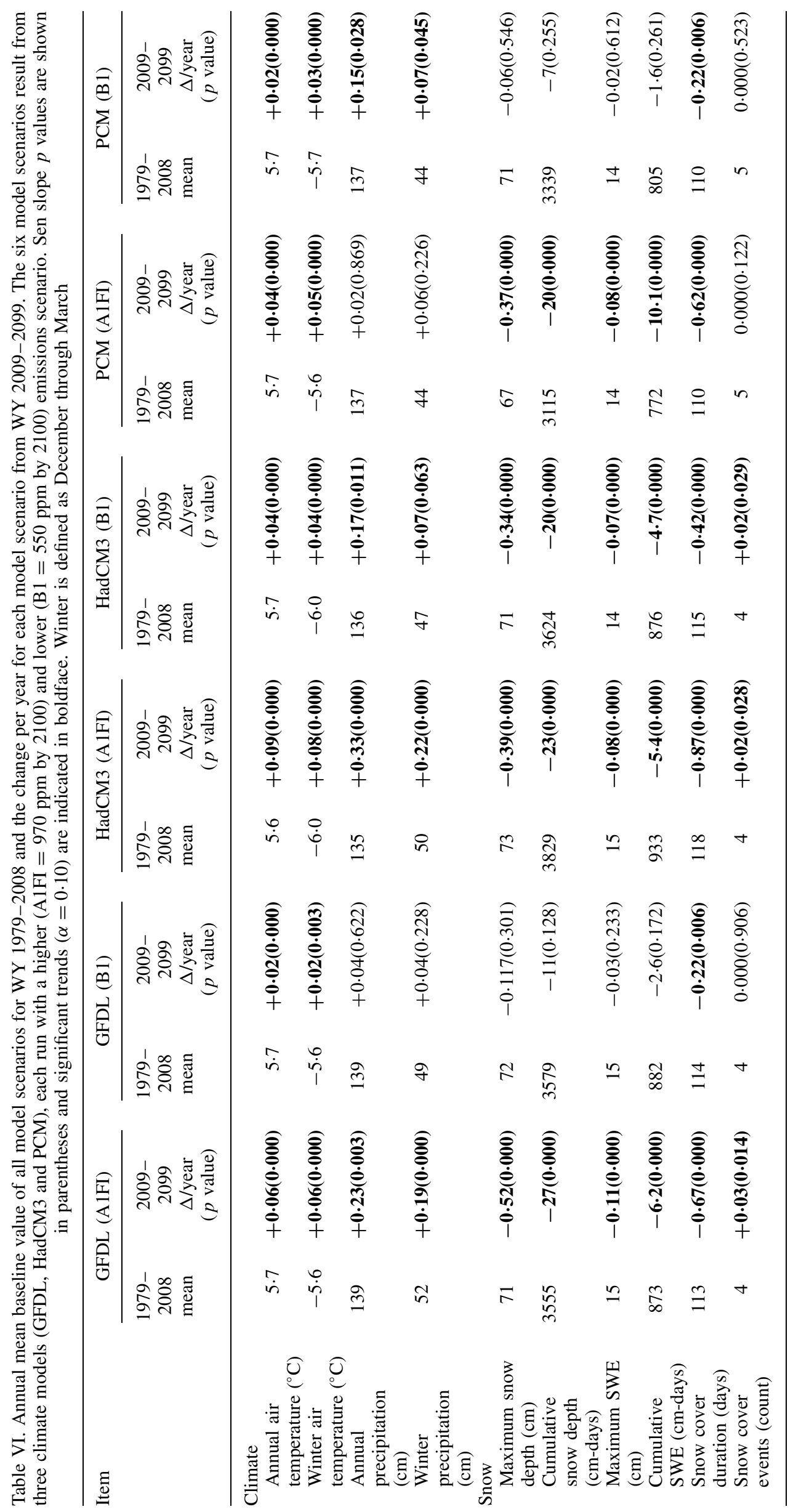



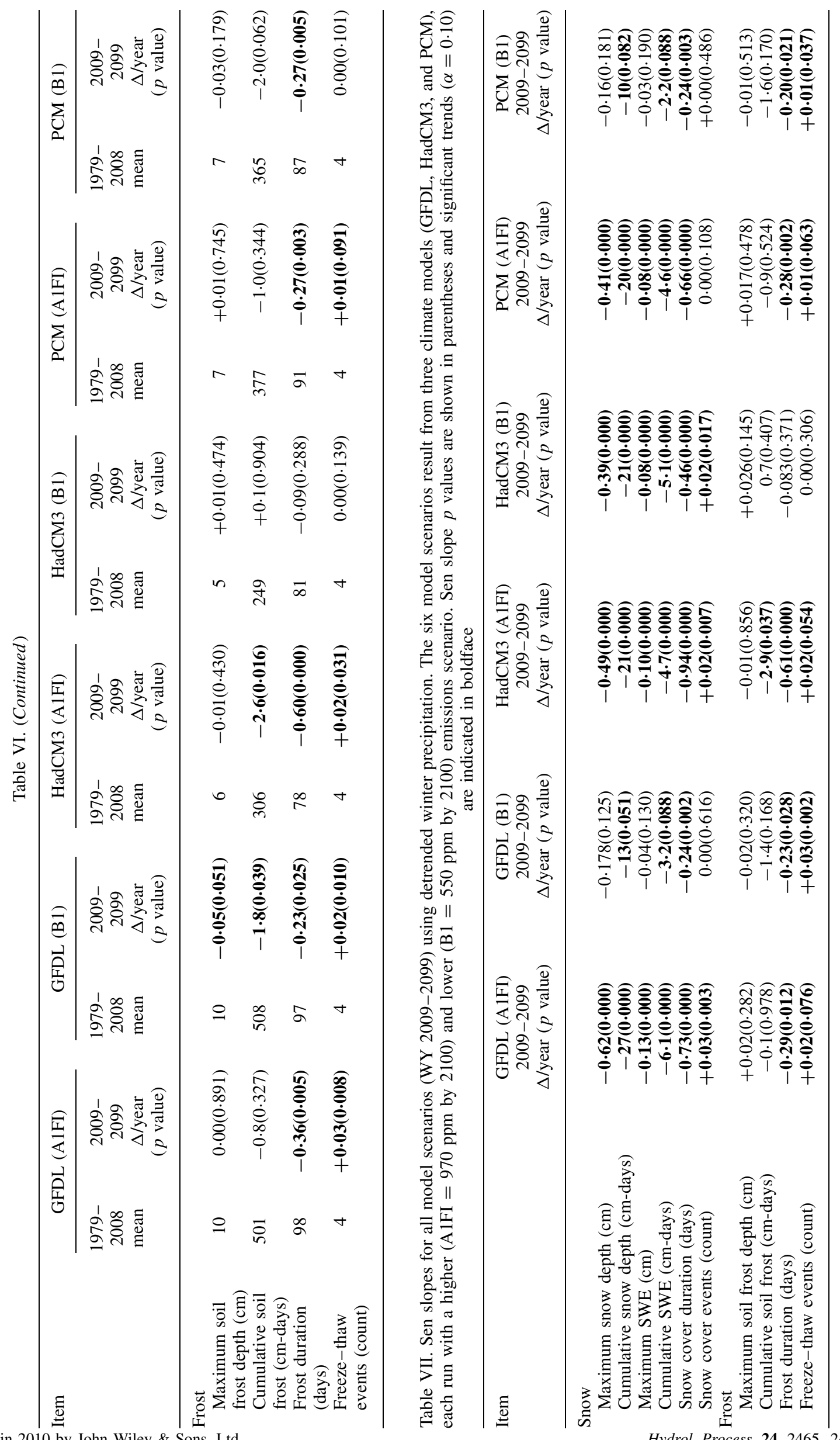


\section{DISCUSSION}

\section{Changes in climate at Hubbard Brook}

Past and projected future changes in temperature and precipitation provide clear evidence that the climate at the HBEF is changing. Although mean annual temperature is variable, all locations evaluated showed an upward trend, ranging from 0.017 to $0.028^{\circ} \mathrm{C}$ per year over the last half century. These changes are consistent with trends that have occurred throughout the northeastern US region over the same time period (Keim et al., 2003; Trombulak and Wolfson, 2004; Hayhoe et al., 2007). The range of air temperature among stations at the HBEF was about $2.5^{\circ} \mathrm{C}$, arising primarily from differences in elevation and aspect (Table III; Figure 2A). Projected increases in future average annual air temperature ranged from 0.02 to $0.09^{\circ} \mathrm{C}$ per year (Table VI), with the higher emission scenarios producing greater increases and lower emission scenarios producing increases that are consistent with trends observed over the recent past. Winter air temperatures at the HBEF have warmed from 0.026 to $0.036^{\circ} \mathrm{C}$ per year since measurements began in the mid1950s (Figure 2B), which is 0.008 to $0.018^{\circ} \mathrm{C}$ per year more than the increase in annual air temperatures. This pattern of increasing winter temperatures is consistent with observed trends across the greater northeastern US region (Burakowski et al., 2008). In contrast, the downscaled climate model projections indicate nearly identical changes in annual versus winter air temperatures for 2009 through 2099.

Annual precipitation volume increased over the available measurement periods at most of the HBEF's hydrometeorologic stations (Table III). These changes were not significant at some of the rain gages with shorter records (i.e. 43-44 years) and trends at longer-running stations were influenced by an extended period of drought in the 1960s (Figure 3) (Namias, 1966).

Despite projections that winter precipitation will increase dramatically over the next century, historical data show no indication of this trend at the HBEF (Table III) or elsewhere in the region (Hayhoe et al., 2007). The past increase in annual precipitation is not a result of changes in winter precipitation, but rather arises from a precipitation increase that is fairly evenly distributed among the other seasons (Hayhoe et al., 2007). Modelled changes in annual average precipitation were consistently lower than the observed trends during 1957-2008, and in two cases (GFDL B1; PCM A1FI) were not significant (Tables III and VI). In contrast to historical trends, winter precipitation is projected to increase and contributes to projected increases in annual precipitation volume.

\section{Observed patterns of snowpack and soil frost}

Changes in climate have led to a reduction in the snowpack at the HBEF (Table IV). At station 2, all metrics we investigated showed significant snowpack declines. The record at station 17 is 10 years shorter than the record at station 2, and only showed significant declines in cumulative SWE. However, the direction and extent of change for the other snow metrics were comparable to station 2. Similar trends in snow depth and SWE from snow courses in Maine have been reported by Hodgkins and Dudley (2006), with nearly $80 \%$ of sites evaluated showing significant declines. Changes in the number of snow-covered days have been evaluated for the greater northeastern United States by Burakowski et al. (2008) who reported an average regional decrease of 3.6 days per decade for 1965-2005, comparable to the 3.9 days per decade decrease at station 2 in our study over a slightly longer time period (1956-2008).

The absence of a significant trend in winter precipitation at the HBEF suggests that the recent decline in snowpack has not been caused by changes in precipitation volume. Other factors that could contribute to declining snowpack include enhanced snowmelt associated with warmer winter air temperatures, changes in the proportion of precipitation falling as snow, or changes in other meteorological variables such as solar radiation, relative humidity and wind speed. Across the greater New England region, there has been a decrease in the proportion of winter precipitation falling as snow (Huntington et al., 2004; Burakowski et al., 2008). Similar trends have not been observed at the HBEF, although precipitation type (i.e. rain, snow, mix) has only been recorded since 1979, and its determination is prone to subjectivity.

While observed changes in climate and snowpack might be expected to influence soil frost, we observed no changes in measured maximum annual soil frost depth since measurements began. The few studies that have examined long-term patterns of soil frost have generally shown declines in maximum annual depth in response to climate change (Frauenfeld et al., 2004; Zhao et al., 2004; Hirota et al., 2006). However, most of these studies have been conducted in colder regions of the world that typically experience deeper and more consistent soil frost. At the HBEF, soil frost was absent approximately 1 in every 3 years, depending largely on early winter air temperatures and the timing and amount of snowfall. The high interannual variability in maximum soil frost depth reduces the ability to detect trends (Figure 4). Some of the variability in observed soil frost depth, as well as some of the disagreement between predicted and observed values, could be due to the errors associated with the manual soil frost measurement method. Measurements are conducted at just a single point at each location at weekly time intervals and rely on a subjective determination of whether or not the ground feels frozen. Alternative methods such as soil frost tubes (Ricard et al., 1976) and temperature probes also have limitations and can produce erroneous results. While many different approaches to measuring seasonally frozen ground have been introduced (e.g. time domain reflectometry (Baker et al., 1982), ground penetrating radar (Steelman and Endres, 2009), electrical resistivity (French et al., 2006), all have drawbacks, highlighting a need for more sophisticated approaches and sensors. Despite limitations, soil frost depth has been measured at 
the HBEF with the same method for 47 years and results have internal consistency. For instance, during periods when soil frost was present, recorded measurements did not change radically from week to week (Figure 5). In addition to this temporal consistency, there was also spatial consistency. A comparison of soil frost depth at stations 2 and 17 showed a significant relationship $\left(r^{2}=0.52, p\right.$ value $\left.=0.000\right)$ for years when it was measured at both stations, and the synchrony between stations suggests that the method is capturing the major frost events (Figure 4).

\section{Simulated soil frost: sources of error and future projections}

Snowpack and soil frost were simulated with the SHAW model for the last 30 years using climate input data from the HBEF (Figure 5). Model performance was evaluated by comparing modelled and measured values (Table V). The SHAW model did a reasonably good job of capturing snowpack development and ablation (Figure 5, Table V), although in some instances, the model had difficulties discerning rain versus snow when air temperatures were near the freezing point. For example, during WY91 and WY92, the model over-predicted snowfall at the beginning of the winter because it incorrectly identified precipitation events as snow rather than rain. Because snowpack keeps soils insulated, erroneous prediction of early season snowpack during these two years caused the model to predict an absence of soil frost when, in reality, there was comparatively deep frost, reaching a maximum of nearly $20 \mathrm{~cm}$. This example highlights the importance of adequately simulating snow depth at the beginning of winter when soil frost forms, to minimize error propagation throughout the winter. Difficulties differentiating between rain and snow are more of a limitation for retrospective analyses, and should not inhibit evaluation of future trends, provided that there is an equal probability of mistaking a rainfall event for snow as a snowfall event for rain. In our analysis, although the mean absolute error was high (19-80\%), particularly for soil frost metrics (Table V), the MBE was low for all metrics $(-15$ to $+15 \%)$. These results indicate that the model did not bias estimates of snow or soil frost and suggest that it can be useful for evaluating the general nature of future trends.

The SHAW model was run through the end of the 21st century using statistically downscaled climate projections for the site. Future snow predictions generated by SHAW showed strong declines over the 2009-2099 period, as indicated by nearly all snow metrics for most of the scenarios. Our simulations suggest that snowpack depth could decrease by as much as $67 \%$ and that the number of snow-covered days could decrease by as much as $70 \%$ by the century's end. Such drastic changes in the snowpack have broad implications for ecosystem services such as winter recreation and tourism, water supply and forest products. Additionally, because many plants and animals require snow cover, changes of this magnitude may affect species composition and biodiversity. Changes in snowcover may also generate feedbacks that amplify or diminish change by altering factors such as surface albedo and trace gas exchange (Tranter and Jones, 2001; Groffman et al., 2006; Qu and Hall, 2007).

\section{Colder soils in a warmer world?}

One of the major objectives of this study was to evaluate how a warmer climate would affect future soil frost since it is an important regulator of many ecological processes during winter. It has been suggested that soil frost could increase in response to climate change because there would be less snow insulating soils during winter, thereby exposing soil to cold winter air temperatures. Our results indicate that the response is more complex and suggest that declining snowpack will not lead to increased soil frost if the decline is associated with warmer air temperatures, but may actually result in a reduction in the number of days during which soil frost occurs. Our simulations under projected future climate produced no significant upward or downward trend in maximum annual frost depth for 2009-2099, except for one lower emissions scenario (GFDL B1), which showed a significant decline. The lack of strong trends in projected frost depth is consistent with field measurements during the last half century at the HBEF. Consistent among modelling studies is the finding that climate change significantly shortens the duration of frozen ground (Venäläinen et al., 2001; Henry, 2008). Our modelling analyses showed that the period of frozen ground decreased substantially, by 0.09 to 0.6 days/year under the scenarios we examined. A plausible explanation for the lack of trend in soil frost depth is that even though reductions in snow depth expose the soil to cold winter air and increase the probability of freezing, frost penetration is limited by warmer air temperatures and a shorter winter season. Hence, under future climate scenarios, soil is not exposed to prolonged periods of extremely cold weather, necessary for developing deep soil frost.

SHAW model results also showed projected increases in the number of annual freeze-thaw events (Table VI). Freeze-thaw events are influenced by the number of snow cover events, which were also projected to increase. Increases in freeze-thaw events were reported in a modelling study that examined soil temperatures at sites across Canada through 2050 (Henry, 2008). However, the increases projected in our study were comparatively minor (0.01-0.03 events per year through 2099). Surprisingly few freeze-thaw events occur at the $\mathrm{HBEF}$, with the modelled mean for 1979-2008 averaging four events per year. Freeze-thaw events can enhance ecological processes such as litter decomposition, mineralization and trace gas fluxes (Schimel and Clein, 1996; Matzner and Borken, 2008). However, past studies have often used unrealistically extreme temperatures and rates of freezing and thawing relative to those that occur naturally in the field (Lipson et al., 2000; Henry, 2007).

Precipitation is a potentially important factor influencing snowpack depth and hence, soil frost. Venäläinen 
et al. (2001) attributed simulated declines in frost depth through 2100 in northern Finland to a 30\% projected increase in winter precipitation. In southern Finland, where precipitation was projected to increase by a much smaller amount, the probability of frozen ground increased significantly. Precipitation is highly spatially and temporally variable and there is uncertainty about how it might change in the future. Although climate model projections for the HBEF suggest that winter precipitation will increase during the 21 st century, there has been no evidence for such a trend over the past half century. If winter precipitation does not increase as projected, future declines in the snowpack may be greater than those shown in Table VI. However, model runs with detrended winter precipitation (Table VII) were very similar to model runs without detrended precipitation, suggesting that the increase in precipitation volume did not have a major influence on the overall trends in snow and soil frost. These results suggest that future increases in precipitation are less important than other factors, such as increases in air temperature, in regulating the snowpack and soil frost.

\section{CONCLUSIONS}

It has been widely reported in the literature that climate change in temperate regions could cause an increase in soil frost, but few data or analyses have been presented to support these suppositions. Our results from long-term frost depth measurements at the HBEF suggest negligible changes in maximum annual frost depth over the past half century. Further, simulations using a soil energy and water balance model suggest little change over the period from 2009 to 2099, when projected declines in winter snowpack are associated with warmer air temperatures. Our simulations indicate that the number of freeze-thaw events will increase slightly in response to climate change depending on the climate models and emission scenarios used. The most important change in soil frost is a projected shortening of the period of frozen ground, coincident with a shorter period of snow cover. Future research should focus on how fewer days with frozen ground might affect factors such as phenology of plants and organisms, hydrologic flow paths, nutrient cycling and trace gas exchange fluxes. The lack of automated field methods for measuring soil frost is currently a barrier for monitoring change. Advances in technology may improve trend detection and will enhance our ability to more fully evaluate soil frost models.

\section{ACKNOWLEDGEMENTS}

The authors would like to thank Bob Smith for helping in compiling the data. Doug Burns, Sheila Christopher and two anonymous reviewers provided helpful comments on earlier drafts of this manuscript. Funding for this work was provided by the USDA Forest Service, Northern Research Station, Newtown Square, PA. This manuscript is a contribution of the Hubbard Brook Ecosystem Study. Hubbard Brook is part of the Long-Term Ecological Research (LTER) network, which is supported by the National Science Foundation. The Hubbard Brook Experimental Forest is operated and maintained by the USDA Forest Service.

\section{REFERENCES}

Bailey AS, Hornbeck JW, Campbell JC, Eagar C. 2003. Hydrometeorological database for Hubbard Brook Experimental Forest: 1955-2000. Gen. Tech. Rep. NE-305. Newtown Square, U.S. Department of Agriculture, Forest Service, Northeastern Research Station: PA; 36.

Baker THW, Davis JL, Hayhoe HN, Topp GC. 1982. Locating the frozen/unfrozen interface in soils using time-domain refletometry. Canadian Geotechnical Journal 19: 511-517.

Banin A, Anderson DM. 1974. Effects of salt concentration changes during freezing on the unfrozen water content of porous materials. Water Resources Research 10: 124-128.

Birkebak R, Birkebak R. 1964. Solar radiation characteristics of tree leaves. Ecology 45: 646-649.

Bormann FH, Likens GE. 1979. Pattern and Process in a Forested Ecosystem. Springer-Verlag: New York; 253.

Boutin R, Robitaille G. 1994. Increased soil nitrate losses under mature sugar maples trees affected by experimentally induced deep frost. Canadian Journal of Forest Research 25: 588-602.

Burakowski EA, Wake CP, Braswell B, Brown DP. 2008. Trends in wintertime climate in the northeastern United States: 1965-2005. Journal of Geophysical Research 113: DOI: 10.1029/2008JD009870.

Clapp RB, Hornberger GM. 1978. Empirical equations for some soil hydraulic properties. Water Resources Research 14: 601-604.

Cleavitt NL, Fahey TJ, Groffman PM, Hardy JP, Henry KS, Driscoll CT. 2008. Winter injury by soil freezing to fine roots of mature trees in a northern hardwood forest. Canadian Journal of Forest Research 38: $82-91$.

Decker KLM, Wang D, Waite C, Sherbatskoy T. 2003. Snow removal and ambient air temperature effects of forest soil temperatures in northern Vermont. Soil Science Society of America Journal 67: $1234-1242$.

DeGaetano AT, Wilks DS, McKay M. 1997. Extreme-value statistics for frost penetration depths in northeastern United States. Journal of Geotechnical and Geoenvironmental Engineering 123: 828-835.

Delworth TL, Broccoli AJ, Rosati A, Stouffer RJ, Balaji V, Beesley JT, Cooke WF, Dixon KW, Dunne J, Dunne KA, Durachta JW, Findell KL, Ginoux P, Gnanadesikan A, Gordon CT, Griffies SM, Gudgel R, Harrison MJ, Held IM, Hemler RS, Horowitz LW, Klein SA, Knutson TR, Kushner PJ, Langenhorst AL, Lee H-C, Lin SJ, Lu J, Malyshev SL, Milly PC, Ramaswamy V, Russell J, Schwarzkopf MD, Shevliakova E, Sirutis J, Spelman M, Stern WF, Winton M, Wittenberg AT, Wyman B, Zeng F, Zhang R. 2006. GFDL's CM2 global coupled climate models. Part 1: Formulation and simulation characteristics. Journal of Climate 19: $643-674$.

Federer CA. 1971. Solar radiation absorption by leafless hardwood forests. Agricultural Meteorology 9: 3-20.

Federer CA. 1977. Leaf resistance and xylem potential differ among broadleaved species. Forest Science 23: 411-419.

Federer CA. 1982. Subjectivity in the separation of organic horizons of the forest floor. Soil Science Society of America Journal 46: 1090-1093.

Federer CA. 1983. Nitrogen mineralization and nitrification: depth variation in four New England forest soils. Soil Science Society of America Journal 47: 1008-1014.

Federer CA. 2002. BROOK90: a simulation model for evaporation, soil water, and streamflow, Version 4.4. Computer Shareware and Documentation. USDA Forest Service, Northern Research Station, Durham, NH.

Fitzhugh RD, Driscoll CT, Groffman PM, Tierney GL, Fahey TJ, Hardy JP. 2001. Effects of soil freezing disturbance on soil solution nitrogen, phosphorus, and carbon chemistry in a northern hardwood ecosystem. Biogeochemistry 56: 215-238.

Fitzhugh RD, Likens GE, Driscoll CT, Mitchell MJ, Groffman PM, Fahey TJ, Hardy JP. 2003. Role of soil freezing events in interannual patterns of stream chemistry at the Hubbard Brook Experimental Forest, New Hampshire. Environmental Science and Technology 37: $1575-1580$. 
Flerchinger GN. 1991. Sensitivity of soil freezing simulated by the SHAW model. Transactions of the American Society of Agricultural Engineers 34: 2381-2389.

Flerchinger GN. 2000. The Simultaneous Heat and Water (SHAW) Model: User's Manual. Northwest Watershed Research Center, USDA Agricultural Research Service: Boise, ID. Technical Report NWRC 2000-10.

Flerchinger GN, Baker JM, Spaans EJA. 1996. A test of the radiative energy balance of the SHAW model for snowcover. Hydrological Processes 10: 1359-1367.

Flerchinger GN, Cooley KR, Deng Y. 1994. Impacts of spatially and temporally varying snowmelt on subsurface flow in a mountainous watershed: 1. Snowmelt simulation. Hydrological Sciences Journal 39: 507-520.

Flerchinger GN, Hardegree SP. 2004. Modelling near-surface temperature and moisture of post-wildfire seedbed for germination response predictions. Journal of Arid Environments 59: 369-385.

Flerchinger GN, Kustas WP, Weltz MA. 1998. simulating surface energy fluxes and radiometric surface temperatures for two arid vegetation communities using the SHAW model. Journal of Applied Meteorology 37: 449-460.

Flerchinger GN, Pierson FB. 1991. Modeling plant canopy effects on variability of soil temperature and water. Agriculture and Forest Meteorology 56: 227-246.

Flerchinger GN, Saxton KE. 1989. Simultaneous heat and water model of a freezing snow-residue-soil system I. Theory and development. Transactions of the American Society of Agricultural Engineers 32: $565-571$.

Flerchinger GN, Seyfried MS, Hardegree SP. 2006. Using soil freezing characteristics to model multi-season soil water dynamics. Vadose Zone Journal 5: 1143-1153.

Frauenfeld OW, Zhang T, Barry RG. 2004. Interdecadal changes in seasonal freeze and thaw depths in Russia. Journal of Geophysical Research 109: DOI: 10.1029/2003JD004245, 002004.

French HK, Binley A, Kharkhordin I, Kulessa B, Krylov SS. 2006. Cold regions hydrogeophysics: physical characterization and monitoring. In Applied Hydrogeophysics, Vereecken H, Binley A, Cassiani G, Revil A, Titov K (eds). Springer: Dordrecht, The Netherlands.

Gilbert RO. 1987. Statistical Methods for Environmental Pollution Monitoring. John Wiley \& Sons: New York; 336.

Groffman PM, Driscoll CT, Fahey TJ, Hardy JP, Fitzhugh RD, Tierney GL. 2001. Colder soils in a warmer world: a snow manipulation study in a northern hardwood forest ecosystem. Biogeochemistry 56: $135-150$.

Groffman PM, Hardy JP, Driscoll CT, Fahey TJ. 2006. Snow depth, soil freezing, and trace gas fluxes in a northern hardwood forest. Global Change Biology 12: 1748-1760.

Hayhoe K, Wake C, Anderson B, Liang X, Maurer E, Zhu J, Bradbury J, DeGaetano A, Stoner A, Wuebbles D. 2008. Regional climate change projections for the Northeast USA. Mitigation and Adaptation Strategies for Global Change 13: 425-436.

Hayhoe K, Wake CP, Huntington TG, Luo L, Schwartz MD, Sheffield J, Wood E, Anderson B, Bradbury J, DeGaetano A, Troy TJ, Wolfe D. 2007. Past and future changes in climate and hydrological indicators in the US Northeast. Climate Dynamics 28: 381-407.

Helsel DR, Hirsch RM. 1992. Statistical Methods in Water Resources. Elsevier Science: Amsterdam; 522

Henry HAL. 2007. Soil freeze-thaw cycle experiments: trends, methodological weaknesses and suggested improvements. Soil Biology \& Biochemistry 39: 977-986.

Henry HAL. 2008. Climate change and soil freezing dynamics: historical trends and projected changes. Climatic Change 87: 421-434.

Hirota T, Iwata Y, Hayashi M, Suzuki S, Hamasaki T, Semeshima R, Takayabu I. 2006. Decreasing soil frost depth and its relation to climate change in Tokachi, Hokkaido, Japan. Journal of the Meteorological Society of Japan 84: 821-833.

Hodgkins GA, Dudley RW. 2006. Changes in late-winter snowpack depth, water equivalent, and density in Maine, 1926-2004. Hydrological Processes 20: 741-751.

Hong B, Swaney DP, Woodbury PB, Weinstein DA. 2005. Long-term nitrate export pattern from Hubbard Brook Watershed 6 driven by climatic variation. Water, Air, and Soil Pollution 160: 293-326.

Huntington TG, Hodgkins GA, Keim BD, Dudley RW. 2004. Changes in the proportion of precipitation occurring as snow in New England (1949-2000). Journal of Climate 17: 2626-2636.

Hymer DC, Moran MS, Keefer TO. 2000. Soil water evaluation using a hydrologic model and calibrated sensor network. Soil Science Society of America Journal 64: 319-326.
IPCC. 2007. Intergovernmental panel on Climate Change Data Distribution Centre (http://www.ipcc-data.org).

Isard SA, Schaetzl RJ. 1998. Effects of winter weather conditions on soil freezing in southern Michigan. Physical Geography 19: 71-94.

Iwata Y, Hayashi M, Hirota T. 2008. Comparison of snowmelt infiltration under different soil-freezing conditions influenced by snow cover. Vadose Zone Journal 7: 79-86.

Johnson CE, Johnson AH, Huntington TG, Siccama TG. 1991a. Wholetree clear-cutting effects on soil horizons and organic-matter pools. Soil Science Society of America Journal 55: 497-502.

Johnson CE, Johnson AH, Siccama TG. 1991b. Whole-tree clear-cutting effects on exchangeable cations and soil acidity. Soil Science Society of America Journal 55: 502-508.

Keim BD, Wilson AM, Wake CP, Huntington TG. 2003. Are there spurious temperature trends in the United States Climate Division database? Geophysical Research Letters 30: DOI: 10.1029/2002GL016295.

Kendall M. 1938. A new measure of rank correlation. Biometrika 30: $81-93$

Kennedy I, Sharrot B. 1998. Model comparisons to simulate soil frost depth. Soil Science 163: 636-645.

Lin C, McCool DK. 2006. Simulating snowmelt and soil frost depth by an energy budget approach. Transactions of the American Society of Agricultural and Biological Engineers 49: 1383-1394.

Lipson DA, Schmidt SK, Monson RK. 2000. Carbon availability and temperature control the post-snowmelt decline in alpine soil microbial biomass. Soil Biology and Biochemistry 32: 441-448.

Lovett GM, Rueth H. 1999. Soil nitrogen transformations in beech and maple stands along a nitrogen deposition gradient. Ecological Applications 9: 1330-1344.

Marion GM. 1995. Freeze-Thaw Processes and Soil Chemistry. Special Report 95-12. U.S. Army Corps of Engineers, Cold Regions Research \& Engineering Laboratory: Hanover, NH; 23.

Matzner E, Borken W. 2008. Do freeze-thaw events enhance C and N losses from soils of different ecosystems? A review. European Journal of Soil Science 59: 274-284.

Nakicenovic N, Alcamo J, Davis G, de Vries B, Fenhann J, Gaffin S, Gregory K, Grubler A, Jung TY, Kram T, La Rovere EL, Michaelis L, Mori S, Morita T, Pepper W, Pitcher HM, Price L, Riahi K, Roehrl A, Rogner H, Sankovski A, Schlesinger M, Shukla P, Smith SJ, Swart R, van Rooijen S, Victor N, Dadi Z. 2001. Special Report on Emissions Scenarios : a special report of Working Group III of the Intergovernmental Panel on Climate Change. Cambridge University Press: New York, NY; 595.

Namias J. 1966. Nature and possible causes of the northeastern United States drought during 1962-65. Monthly Weather Review 94: 543-554.

Ollinger SV, Goodale CL, Hayhoe K, Jenkins JP. 2008. Potential effects of climate change and rising $\mathrm{CO}_{2}$ on ecosystem processes in northeastern U.S. forests. Mitigation and Adaptation Strategies for Global Change 13: 467-485.

Plummer DA, Caya D, Frigon A, Côté H, Giguère M, Paquin D, Biner S, Harvey R, de Elia R. 2006. Climate and climate change over North America as simulated by the Canadian RCM. Journal of Climate 19: $3112-3132$.

Pope VD, Gallani ML, Rowntree PR, Stratton RA. 2000. The impact of new physical parametrizations in the Hadley Centre climate model-HadAM3. Climate Dynamics 16: 123-146.

Preston GM, McBride RA. 2004. Assessing the use of poplar tree systems as a landfill evapotranspiration barrier with the SHAW model. Waste Management \& Research 22: 291-305.

Qu X, Hall A. 2007. What controls the strength of snow-albedo feedback?. Journal of Climate 20: 3971-3981.

Rhoads AG, Hamburg SP, Fahey TJ, Siccama TG, Kobe RK. 2004. Comparing direct and indirect methods of assessing canopy structure in a northern hardwood forest. Canadian Journal of Forest Research 34: $584-591$.

Ricard JA, Tobiasson W, Greatorex A. 1976. The field assembled frost gage. Technical Note. Cold Regions Research and Engineering Laboratory: U.S. Army Corps of Engineers, Hanover, NH.

Schimel JP, Clein JS. 1996. Microbial response to freeze-thaw cycles in tundara and taiga soils. Soil Biology and Biochemistry 8: 1061-1066.

Sen PK. 1968. Estimates of the regression coefficient based on Kendall's tau. Journal of the American Statistical Association 63: 1379-1389.

Shanley JB, Chalmers A. 1999. The effect of frozen soil on snowmelt runoff at Sleepers River, Vermont. Hydrological Processes 13: $1843-1857$.

Siccama TG, Fahey TJ, Johnson CE, Sherry TW, Denny EG, Girdler EB, Likens GE, Schwarz PA. 2007. Population and biomass dynamics of trees in a northern hardwood forest at Hubbard Brook. Canadian Journal of Forest Research 37: 737-749. 
Soil Conservation Service. 1984. Snow-Survey Sampling Guide. USDA Soil Conservation Service Agriculture Handbook 169, U.S. Government Printing Office: Washington DC.

Steelman CM, Endres AL. 2009. Evolution of high-frequency groundpenetrating radar direct ground wave propagation during thin frozen soil layer development. Cold Regions Science and Technology 57: $116-122$.

Sulkava P, Huhta V. 2003. Effects of hard frost and freeze-thaw cycles on decomposer communities and $\mathrm{N}$ mineralisation in boreal forest soil. Applied Soil Ecology 22: 225-239.

Tetens O. 1930. Über einige meteorologische begriffe. Zeitschrift für Geophysik 6: 297-309.

Tierney GL, Fahey TJ, Groffman P, Hardy JP, Fitzhugh RD, Driscoll CT. 2001. Soil freezing alters fine root dynamics in a northern hardwood forest. Biogeochemistry 56: 175-190.

Tranter M, Jones HG. 2001. The chemistry of snow: Processes and nutrient cycling. In Snow Ecology, Jones HG, Pomeroy JW, Walker DA, Hoham RW (eds). Cambridge University Press: New York; 378.
Trombulak SC, Wolfson R. 2004. Twentieth-century climate change in New England and New York, USA. Geophysical Research Letters 31: DOI: $10.1029 / 2004 G L 020574$.

Venäläinen A, Tuomenvirta H, Heikinheimo M, Kellomäki S, Peltola H, Strandman H, Väisänen H. 2001. Impact of climate change on soil frost under snow cover in a forested landscape. Climate Research 17: 63-72.

Washington WM, Weatherly JW, Meehl GA, Semtner AJ, Bettge TW, Craig AP, Strand WG, Arblaster JM, Wayland VB, James R, Zhang J. 2000. Parallel climate model (PCM) control and transient simulations. Climate Dynamics 16: 755-774.

Zhang T, Barry RG, Armstrong RL. 2004. Application of satellite remote sensing techniques to frozen ground studies. Polar Geography $\mathbf{2 8}$ : 163-196.

Zhao L, Ping C, Yang D, Cheng G, Ding Y, Liu S. 2004. Changes of climate and seasonally frozen ground over the past 30 years in Qinghai-Xizang (Tibetan) Plateau, China. Global and Planetary Change 43: 19-31. 